\title{
La herencia de Scherezada
}

\author{
Por Miguel Ángel Manrique ${ }^{1}$ \\ Universidad del Externado
}

Voy a hablarles de la ficción. El Diccionario de la Lengua Española relaciona esta palabra con fingir, que significa simular. Dar existencia ideal, dice, a lo que realmente no la tiene. La ficción se relaciona con la invención, con la creación imaginaria, con la fantasía, con la literatura. Por eso decimos que Las mil y una noches es una ficción, así como Moby Dick o Los tres mosqueteros. Cada una de estas historias finge una serie de situaciones: Sherezada distrayendo al rey con maravillosos relatos; el capitán Ahab luchando contra una ballena blanca; el joven D'Artagnan construyendo su destino en París. Por tradición sabemos quiénes son Sherezada, el capitán Ahab y D’Artagnan. Casi resultan más conocidos que nuestros vecinos. A diferencia de nuestros vecinos, sin embargo, a quienes podríamos encontrar en la calle para conversar, los personajes mencionados sólo existen dentro de las obras literarias en las que fueron concebidos. Son personajes de ficción; están hechos de palabras.

Ahora pensemos en otras tres historias. Por ejemplo, en A sangre fría, de Truman Capote, Hiroshima, de John Hersey, o Viajes con Heródoto, de Ryzard Kapucinski. También son narraciones que fingen otras situaciones: el asesinato de la familia Clutter a manos de dos asesinos llamados Dick y Perry; la forma cómo la señorita Toshiko Sasaki sobrevivió a la bomba atómica; la aventura de un joven periodista polaco en la China de Mao. Contrariamente a los personajes anteriores, Dick y Perry, Toshiko Sasaki y Ryzard Kapucinski existieron. Los dos primeros fueron condenados a la horca en 1965, la segunda se convirtió en 1957 en la hermana Dominique Sasaki, y el último, autor de libros de viajes como Ébano, El Sha y El imperio, murió en

\footnotetext{
${ }^{1}$ Estudios de Literatura en la Universidad Nacional de Colombia, con especialización en Ciencias de la Comunicación de la Universidad Autónoma de Barcelona. Magíster en Educación de la Universidad Externando de Colombia. Autor de los libros de relatos La mirada enferma (2005) y Confesiones de un mutante (2002).
} 
enero del 2007. Estas personas, no obstante, se transformaron en personajes de estos libros, se trasmutaron en palabras, se volvieron ficción.

Toda narración surge de una interpretación del mundo real. El mundo real está regido por su propias leyes: si llueve nos cubrimos con un paraguas para no mojarnos, si nos da hambre comemos, si sueño, dormimos. En cambio en la ficción literaria los aguaceros, el hambre y los sueños son de papel. El mundo de la ficción también se comporta de acuerdo con sus propias leyes. Por tanto, no recurriré aquí a la oposición ficción-no-ficción, por considerar la no-ficción literaria una contradicción. Toda literatura es ficción, pero no toda ficción es literatura. Porque la ficción es un atributo de lo literario, pero no es el único. Están también el uso del lenguaje, el estilo, la estructura de la obra y la imaginación del artista.

Ahora bien, ficción no se opone a realidad, porque la realidad es un concepto y, por tanto una construcción. Así que la pretensión de muchos escritores de no-ficción de estar hablando de la realidad es falaz. Se objetará que la ficción tiene grados de verosimilitud, mientras que la no-ficción tiende a la veracidad. Estoy de acuerdo, sin embargo, con Juan José Saer cuando afirma que: "Todo lo que es verificable en este tipo de relatos (de no ficción) es en general anecdótico y secundario". La pretendida literatura de no-ficción, aunque reconozco que se fundamenta en datos y en información veraz, crea versiones de la realidad. Excluir, como dice Saer, lo ficticio en una novela de no-ficción, como llamó Truman Capote a A sangre fría, no es un criterio de verdad ni de veracidad. Porque por más rigurosos y documentados que estén los escritores, trabajan con el lenguaje. Decía Tolstoi de la Historia que era una gran fábula, una ficción. El paso de la Historia se nos escapa constantemente y por más que intentemos retener un hecho y verificarlo como real no pasa de ser un punto de vista, una interpretación.

El periodismo literario, por ejemplo, pretende hacer no-ficción. Sus relatos deben aceptar las reglas del realismo, es decir, los procedimientos que utilizaron los escritores realistas del siglo XIX como Dickens y Balzac que, según Tom Wolfe, son: la construcción escena por escena, el diálogo realista, la elección de varios puntos de vista y la descripción de elementos simbólicos. Pues gracias a estas técnicas nació el llamado Nuevo Periodismo en la década de los sesenta en los Estados Unidos. Periodistas como John Hersey, Truman Capote y Norman Mailer, se dedicaron a escribir relatos de no-ficción utilizando el método. 
¿Qué significaba este descubrimiento? Que, a diferencia de los novelistas de ficción los cuales, según Wolfe, se encerraron en sus torres de marfil esperando crear novelas inspirados por las musas, los periodistas se dedicaron a investigar, a observar situaciones reales, a describirlas y narrarlas. Se comportaron un poco como etnógrafos y un poco como historiadores. Es decir, la no-ficción provino de utilizar lo datos, las estadísticas, los testimonios y los documentos que probaban que lo que se contaba había ocurrido realmente. Para hacerle honor a la veracidad de la información, la revista The New Yorker, como cuenta el cronista gringo George Packer en una entrevista realizada por El Espectador, tiene un departamento de verificación de datos. Dice Packer que es una sección completa de la revista integrada por dieciséis jóvenes inteligentes encargados de verificar la información del artículo que el periodista va a publicar.

Ahora bien, ¿qué diferencias desde el punto de la ficción pueden existir entre Satanás, de Mario Mendoza y La guaca Maldita, de Jörg Hiller? Desde mi punto de vista, ninguna: Campo Elías Delgado fue tan real como el teniente Jorge Sanabria Acevedo. La diferencia radica más en la propuesta retórica planteada al lector: en la primera obra se realiza un pacto con la ficción, así el autor tiene derecho a imaginar o inventar su versión de los hechos y el lector los acepta sin cuestionarlos. En la segunda, en cambio, se le hace creer al lector que se está contando una historia real, las "revelaciones del teniente que sabe dónde está el tesoro de las FARC". El hecho de que sea un testimonio lo hace más veraz. No obstante, recordando a Saer, la veracidad "es un supuesto retórico de un género literario". Es posible que en la obra de Jörg Hiller la mayoría de las anécdotas sean ciertas, pero apenas es una versión de lo que sucedió realmente, una construcción verbal del hecho, una interpretación periodística del testimonio del teniente, aparentemente objetiva.

Para terminar, básteme decir que, en tanto géneros literarios, la crónica periodística y la novela son diferentes maneras de la ficción. 0 , como diría Borges, diferentes maneras de postular la realidad.

Bogotá, 26 de agosto de 2008 